\title{
Interaction in Distance Education: Student, Teaching Material, Information Technology and Communication
}

\author{
Sônia Regina Gouvêa Rezende, Valter Gomes Campos, \\ Pollyana dos Reis Pereira Fantone, and Melca Moura Brasil \\ State University of Goiás-UEG \\ soniarez2@yahoo.com.br, \{valtergc1,pollyana_reis\}@hotmail.com, \\ melacabrasilegmail.com
}

\begin{abstract}
Distance education requires the development and production of teaching materials with their own peculiarities, on which stand out the clarity, objectivity, the interactivity and the reference to the dialogue. These characteristics imply the qualification of teachers for the development of differentiated skills and competencies for their manufacture. This article presents the methodology of the course "Development and Production of Teaching Materials for Distance Education", in the State University of Goiás - UEG. At first it is presented the demanded qualifications of the content teacher that needs to master the covered content and be able to promote student motivation, prompting him to search for knowledge. Still, in this context, it discusses the specifics of teaching materials for distance education. In the second phase, it presents the historical background of the university, its work in this area and its future challenges. As a last step, it describes the methodology used in the course of the University Unit of Distance Education (UnUEAD) UEG to train its teachers to act as content teachers of teaching material for this type of education. This methodology consists of the following phases: planning, structure and organization of the course. The design is characterized by the construction of the conceptual map, a tool that assists in defining the theoretical and practical approaches to be worked. From these fundamentals, the course is structured and its modules are organized. In the final evaluation of the course the content teacher consolidates his learning through the development of the Subject Production Plan and a production of a text, according to the characteristics of materials for distance education. It stands out, as a final consideration of this article, that the development and production of teaching material at UnUEAD is guided by the same methodology used in training its contents teachers.
\end{abstract}

Keywords: Methodology, Distance Education, Instructional Materials, Training, Information Technology and Communication.

\section{Introduction}

The Information and Communication Technologies - ICT and implementation of flexible learning models and intelligent educational activities based on Web, provided a rapid growth of Distance Education (DE), and made it an educational modality even 
more challenging. Information Technologies and Communication alone are not able to promote student learning, so it is necessary that communication can be the focus of the case and planned in a way that is efficient in promoting the interaction among the student, the teacher and knowledge. In this process the didactic material is the key role and requires its own methodology for its preparation, as it has different characteristics and should be well planned and produced and has appropriate language and formatting.

Thus, it is evident the need and importance of the content teacher training to the development of teaching specific materials, appropriate and qualified to distance education requirement. With this vision, the State University of Goiás (UEG), through the Crew Pedagogical University Unit of Distance Education (UnUEAD) developed the course "Training Development and Production of Teaching Materials for Distance Education." To be offered at a distance, gives opportunity to apply the knowledge built as the course develops.

\section{Training Teachers to Work in DE}

Teaching is a complex activity that includes technical and pedagogical questions, knowledge and subjectivities, which requires consistent training. Hence the importance of training institutions, which according to Nóvoa (1995), occupy a central place in the production and reproduction of knowledge and system of standards of the teaching profession and play a fundamental role in the assertion of professional identity. In turn, the teacher must take his professional identity, being a researcher, dealing with everyday school life, with new knowledge and new educational methods.

With the rapid development of knowledge and education in the face of current reality, it is observed that for proper training of educators is not enough just the technical approach and educational content. It is increasingly evident the need for a solid education, which includes the binomial theory and practice and the quest for the development of skills and competencies, especially, learning to learn, research and the use of innovative teaching practices. Learning is essential to the challenges that present itself in the educational context (POZO, 1998).

The use of Information and Communication Technologies - ICT in education has increased in recent years, especially with the expansion of Internet access. This added to the network usage by students has become a major challenge for professionals working in and with education. Thus, it is necessary a comprehensive teacher training, both initial and continuing, that, beyond the mastery of the content covered, teachers are able to use ICT, and select teaching materials and work to promote student motivation in order that it cannot position itself as being passive receiver of information, but as one who instigates the whole time to seek the necessary knowledge for his/her formation.

For this to happen we need to understand education as a practice of social construction of meaning by the individuals who participate and, in this context, understanding the importance of student autonomy, which is accentuated in Distance Education (PRETI, 2000). 
It is therefore important to use methodological strategies that provide autonomy and at the same time, cooperation among students around a didactic purpose, for which ICT has proven very useful. It should be noted, however, that technology should not be seen as an end but as a means to assist in the construction of knowledge, because it itself does not guarantee success in education. Belloni (2009) discusses the use of Information Technologies and Communication becomes the process of teaching and learning more complex, requiring a segmentation of the act of teaching in different and multiple tasks. Therefore, one must understand its pedagogical value, how, and why to use ICT in education.

In this scenario, it is necessary training for the job as content teacher, who is the one responsible for designing and producing educational material in a particular discipline to DE. To act as a content teacher, the teacher must first of all overcome the barriers and rejections of the modality. Secondly, the teacher should have an appropriate profile, manifest by aligning with the Information and Communication Technologies. And, thirdly, he/ she must know the peculiarities and characteristics of teaching materials for distance education, as well as the drafting and production of this material.

\section{Teaching Materials for DL}

In Distance Education the process of teaching and learning takes place primarily through the courseware, because communication happens through interaction with texts and hypertexts, with the authors' interpretation of thinking through writing. In Distance Education, the teaching material is the basis on which sets the methodologies of teaching and interactions. It is one of the main elements of mediation among the subjects of this educational modality, thus it requires different characteristics as to be able to promote communication and dialogical.

The teaching materials for Distance Education must have appropriate language and formatting. In it is important to use teaching resources and methodological strategies that provide autonomy in the context of various forms of cooperation among students around a didactic purpose. It must be carefully planned and presented, taking into account the student's profile and establishing relationships with his/her everyday issues, so that the teaching material is an instrument of permanent dialogue.In this sense, context, clarity, objectivity, and interactivity dialogicity are essential peculiarities and characteristics to the quality of educational material. As Oliveira and Nogueira (2005), to address these specificities, courseware must be prepared by multidisciplinary or transdisciplinary, incorporation and adaptation of technology tools that will be used, the collaboration of tutors and the student as the center of the teaching process learning.

Given this, it is evident the necessity and importance of this training for the professional development of teaching materials specific, appropriate and quality that distance education requires. With this vision, the State University of Goiás (UEG), through the Pedagogical Crew of the University Unit of Distance Education (UnUEAD) developed the course "Training Development and Production of Teaching 
Materials for Distance Education." To be offered at a distance, this course gives opportunity to apply the knowledge built as the course develops. This article aims to describe the methodology used by the State University of Goiás, through the Unit University of Distance Education (UnUEAD), to train its staff in the development and production of teaching material for distance education. It is presented in the first part of this article the need for training of teachers to act as content teacher in distance education. The second part describes the peculiarities of teaching materials for this educational modality and presents techniques for interactivity as the foundation of its development. The last section presents the methodology of the course "Training Development and Production of Teaching Materials for Distance Education." The planning is characterized by the construction of the concept map, a tool that assists in defining the theoretical and practical approaches to be worked. From this foundation, the course is structured and its modules are organized. In the final evaluation of the course content teacher consolidates their learning through the development of the Production Plan of Discipline and production of a text, according to the specificities and characteristics of materials for Distance Education. It stands out as a final consideration of this article, the development and production of teaching materials in the UnUEAD is guided by the same methodology used in the training of its content teachers.

\section{References}

1. Belloni, M.L.: Educação a Distância. São Paulo: Autores associados (2009)

2. Landim, C.M., Das, M.P.F.: Educação a Distância: algumas considerações. Edição do Autor, Rio de Janeiro (1997)

3. Oliveira, E., da, S.G.: e Nogueira, M. L de L. Educação a Distância e Formação Continuada de Professores: novas perspectivas. A revista digital da CVA-RICESU. v. 3 - n.10, nov, Universidade do Estado do Rio de Janeiro (UERJ), Faculdade de Educação - Brasil (2005)

4. Preti, O.: Autonomia do Aprendiz na Educação a Distância: significados e dimensões Disponível, http: / / www . nead. ufmt . br/documentos / autonomia_ooreste_I07.doc. (Acesso March 20, 2011)

5. UnUEAD. Pesquisa realizada nas Unidades Universitárias da Universidade Estadual de Goiás (2010) 